\title{
Hubungan Education terhadap Kecenderungan Fresh Graduate Bekerja Perbandingan Sebelum dan Selama Pandemi Covid 19 (Tahun 2019 dan 2020) di Indonesia
}

\author{
The Relationship of Education to the Trend of Fresh Graduates Working Comparison Before \\ and During the Covid 19 Pandemic (In 2019 and 2020) in Indonesia
}

\author{
Sarah Nurlaily \\ Fakultas Ekonomi dan Bisnis, Universitas Indonesia \\ Jl. Margomda Raya, Pondok Cina, Depok 16424, Indonesia \\ *Korespondensi: Sarahnur141ly@gmail.com
}

[diterima: April 2021- revisi: Juni 2021-diterbitkan daring: Juli 2021]

\begin{abstract}
ABSTRAK
Dampak pandemi covid 19 sangat dirasakan oleh fresh graduate di Dunia, tak terkecuali di Indonesia. Sulitnya mendapatkan pekerjaan selama pandemi, membuat jumlah fresh graduate berpendidikan menengah dan tinggi yang bekerja mengalami penurunan pada tahun 2020 dibanding tahun 2019. Penelitian ini bertujuan untuk menganalisis hubungan education dari pencapaian pendidikan dan keikutsertaan pelatihan terhadap kecenderungan fresh graduate untuk bekerja, dengan menggunakan data Survei angkatan kerja nasional (Sakernas) Agustus tahun 2019 dan 2020 dan metode regresi multilevel. Metode ini digunakan pada data yang bersifat hirarki, yaitu level individu dan makro. Dengan dikontrol oleh karakteristik individu dan Upah Minimum Provinsi (UMP), kecenderungan untuk bekerja fresh graduate lulusan perguruan tinggi meningkat pada tahun 2020 dibanding tahun 2019, namun kecenderungannya untuk bekerja masih lebih rendah dari lulusan SMA. Perguruan tinggi perlu berbenah agar lulusan yang dihasilkan sesuai dengan kebutuhan di pasar kerja. Kuantitas dan kualitas perguruan tinggi tidak dapat dipisahkan.
\end{abstract}

Kata kunci: pendidikan, lulusan baru, pandemi covid 19, multilevel, upah minimum

\begin{abstract}
The impact of the COVID-19 pandemic is very much felt by fresh graduates in the world, including in Indonesia. The difficulty o getting job during pandemic has caused the number of fresh graduates with secondary and higher education who work has decreased in 2020 compared to 2019. This study aims to analyze the relationship between education and training participation on the tendency of fresh graduates to work, using data from the National employment survey (Sakernas) August 2019 and 2020 with multilevel regression. This method is used on hierarchical data at the individual and macro levels. Controlled by individual characteristics and the Provincial Minimum Wage (UMP), the tendency to work for fresh graduates from college graduates increased in 2020 compared to 2019, but the tendency to work was still lower than high school graduates. Universities need to improve so that the graduates produced are in accordance with the needs in the job market. The quantity and quality of universities cannot be separated.
\end{abstract}

Key words: education, fresh graduate, pandemic covid 19, multilevel, minimum wage

JEL Classification: A13, A23, J24 


\section{PENDAHULUAN}

\section{Latar belakang}

Virus covid 19 pertama kali menyebar di Wuhan, China pada Desember 2019, secara resmi masuk Indonesia pada bulan Maret 2020 dan menjadi pandemi hampir di seluruh negara di dunia. Guna mencegah penularan virus, pemerintah Indonesia memperkenalkan adaptasi kebiasaan baru dan pembatasan mobilitas. Kebijakan pembatasan sosial membuat kegiatan ekonomi mengalami pukulan yang berat. Banyak perusahaan yang gulung tikar, menyebabkan tingkat pengangguran meningkat hampir $2 \%$ poin menjadi $7.07 \%$ pada tahun 2020 (BPS, 2020). Hal ini sangat berpengaruh pada kesempatan kerja fresh graduate. Namun tidak semua fresh graduate masuk dalam pasar kerja sebagai angkatan kerja. Jumlah fresh graduate yang lulus pada periode Agustus 2019-Agustus 2020 berjumlah 6.25 juta orang, tetapi yang masuk dalam angkatan kerja hanya 2.47 juta orang. Beberapa diantaranya melanjutkan pendidikan yang lebih tinggi, menikah dan menjadi ibu rumah tangga, maupun alasan lain.

Pada tahun 2019 dan 2020, persentase fresh graduate yang bekerja didominasi oleh lulusan SMP. Persentasenya mengalami kenaikan sebesar $4.9 \%$ poin dari tahun 2019. Persentase fresh graduate lulusan perguruan tinggi, SMA, dan SMK yang bekerja justru mengalami penurunan dibanding tahun 2019.

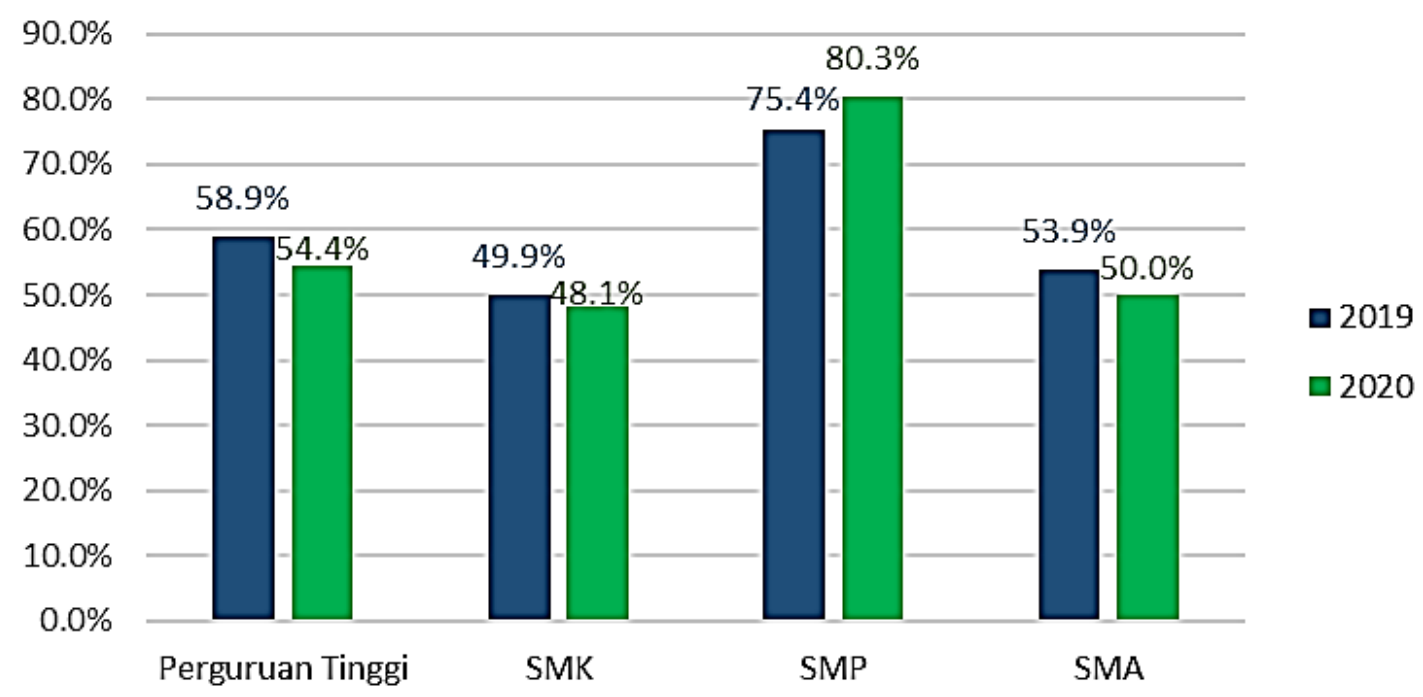

Sumber : Sakernas Agustus (diolah)

Gambar 1. Persentase Fresh Graduate yang Bekerja dari Jumlah Angkatan Kerja Menurut Tingkat Pendidikan

Perumusan masalah dan tujuan penelitian

Dampak pandemi covid 19 sangat dirasakan oleh para fresh graduate di banyak negara. Studi yang dilakukan di 21 negara pada tahun 2020 dimana Indonesia tidak masuk dalam unit analisisnya, memberikan hasil bahwa terjadi penurunan perekrutan pekerja fresh graduate dari semua tingkatan skill (Hooley, 2020).

Di Indonesia, jumlah fresh graduate yang memasuki pasar kerja mengalami peningkatan, dari 2.42 juta orang pada tahun 2019 menjadi
2.47 juta orang pada tahun 2020. Hal ini membuat mereka harus bersaing di tengah pandemi covid 19 dan kontraksi pertumbuhan ekonomi yang melanda. Persaingan tersebut dapat disortir dari education yang melekat pada pekerja.

Penelitian hubungan education dari pencapaian pendidikan dan keikutsertaan pelatihan terhadap kecenderungan fresh graduate bekerja dirasa perlu dilakukan pada masa pandemi covid 19 (tahun 2020) dan dibandingkan 
dengan tahun 2019 agar mengetahui betapa pentingnya pendidikan dan pelatihan dalam menghadapai resesi yang terjadi. Tidak menutup kemungkinan bahwa resesi yang lain dapat terjadi, sehingga Indonesia dapat mempersiapkan kualitas Sumber Daya Manusia (SDM) dari sekarang. Referensi fresh graduate pada individu yang lulus dalam setahun terakhir dan bagi yang bekerja dibatasi dengan pengalaman kerja yang juga dalam setahun terkahir, sehingga lebih menggambarkan kesempatan kerja fresh graduate. Batasan usia antara 15-32 tahun untuk mengakomodir fresh graduate lulusan S3 serta mengikuti konsep UN Habitat mengenai batasan usia pemuda (Wikipedia, 2021). Kecenderung fresh graduate bekerja juga dikontrol oleh kebijakan pemerintah dalam hal penetapan upah minimum provinsi dan dilakukan dengan membandingkan dua titik waktu. Sehingga tujuan penelitian ini adalah untuk mempelajari perbandingan hubungan education terhadap kecenderungan fresh graduate untuk bekerja dibanding menganggur saat sebelum pandemi covid 19 (tahun 2019) dan selama pandemi covid 19 (tahun 2020) di Indonesia.

\section{Tinjauan teori}

Model neoclassical labor-leisure choice (Borjas, 2014) mengemukakan bahwa setiap individu memilih untuk masuk dalam pasar kerja atau tidak. Setelah masuk dalam pasar kerja, setiap individu menentukan jumlah jam kerja dan jam leisure. Kombinasi yang dipilih bertujuan untuk memaksimumkan utilitas. Setiap individu memiliki tingkat utilitas yang berbeda, tergantung pada preferensi dan faktor demografi, sosial, ekonomi lainnya.

Menurut teori human capital (Becker, 1962) menyatakan bahwa investasi pada pendidikan dan pelatihan akan meningkatkan peluang untuk mendapat pekerjaan dan pengembangan karir ke jenjang yang lebih tinggi, sehingga pada akhirnya terjadi peningkatan pendapatan dan konsumsi.

Kebijakan upah minimum yang ditetapkan pemerintah sampai tingkat regional (provinsi maupun kabupaten/kota) diindikasikan dapat memengaruhi fresh graduate untuk bekerja. Kebijakan tersebut bertujuan untuk melindungi pekerja dengan skill dan pengalaman yang minim. Kebijakan ini tidak hanya berdampak positif, tetapi juga berdampak negatif bagi pasar kerja. Penetapan upah minimum dapat meningkatkan cost yang dibayar perusahaan. Bila perusahaan tidak dapat melakukan ekspansi usaha maka akibatnya jumlah pekerja yang dapat dihire akan lebih sedikit dan kesempatan kerja pun menurun. Hal ini dapat memengaruhi fresh graduate yang memasuki pasar kerja. Dalam (Mankiw, 2020) disebutkan bahwa upah minimum menjadi salah satu penyebab adanya pengangguran.

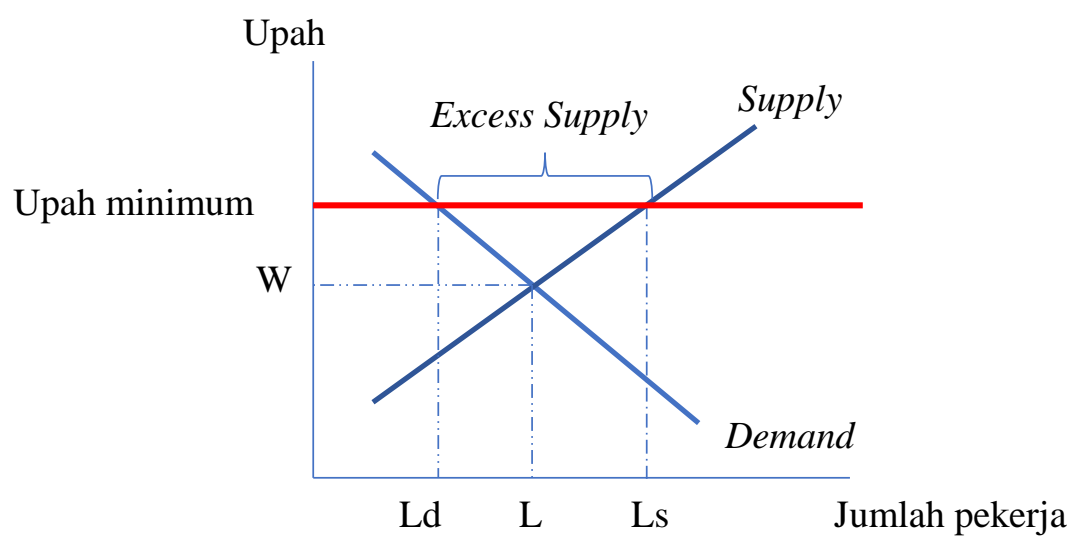

Pada saat upah minimum lebih tinggi dari upah equilibrium, maka jumlah pekerja yang ingin bekerja akan meningkat dari L ke Ls, sedangkan yang dapat dipekerjakan perusahaan menjadi lebih sedikit, yaitu sebesar Ld. Hal tersebut dilakukan perusahaan untuk 
meminimalkan biaya yang akan memaksimumkan keuntungan. Timbul kelebihan jumlah penawaran tenaga kerja, sebagian tenaga kerja menjadi penganggur dan sebagian lagi memasuki pasar kerja informal.

\section{Tinjauan empiris}

1. Education (pendidikan dan pelatihan)

Pada negara Uni Eropa dengan menggunakan data Eurostat tahun 20082020, sebelum terjadinya krisis finansial tahun 2008, persentase penduduk recent graduate bekerja mengalami peningkatan yang konstan, namun setelah tahun 2008 mengalami penurunan dan pada tahun 2014 ekonomi mulai membaik sehingga persentase penduduk recent graduate bekerja terus meningkat sampai tahun 2019. Kemudian pandemi melanda tahun 2020, membuat persentase penduduk recent graduate bekerja, kembali menurun di semua tingkatan pendidikan. Pada data tersebut juga terlihat bahwa semakin tinggi tingkat pendidikan recent graduate maka persentase penduduk bekerja semakin meningkat. Kemudian persentase penduduk bekerja pada recent graduate dari lulusan pendidikan menengah atas kejuruan, lebih tinggi dibanding dari lulusan pendidikan menengah atas umum. Recent graduate yang dimaksud adalah berumur 20-34 tahun yang baru lulus dalam 1-3 tahun terkahir (eurostat, 2021).

Studi yang dilakukan di Swiss antara tahun 2004-2006, menemukan bahwa tingkat pendidikan signifikan dan positif memengaruhi peluang individu mendapat pekerjaan di pasar kerja. Lulusan perguruan tinggi mempunyai peluang yang lebih besar untuk mendapat pekerjaan dibanding dengan tingkat pendidikan di bawahnya. Namun pelatihan tidak signifikan memengaruhi peluang untuk mendapat pekerjaan karena yang diukur adalah durasi pelatihan dan tidak mengukur kualitas dari pelatihan (Wittekind et al., 2010; Dragolea \& Scorte, 2020). Investasi di bidang pendidikan akan meningkatkan kemampuan individu dalam menghadapi perubahan kondisi ekonomi
(Song \& Riddell, 2011) di Amerika Serikat tahun 1980-2005.

2. Umur

Tingkat pengangguran menurun seiring dengan bertambahnya umur, namun pada umur tertentu akan meningkat kembali. Pekerja yang lebih muda cenderung memiliki pengalaman yang lebih terbatas dibanding tenaga kerja yang lebih tua, sehingga lebih cenderung untuk menganggur (BaahBoateng, 2015).

3. Tempat tinggal

Tingkat pengangguran di perkotaan lebih tinggi dibanding di perdesaan. Fasilitas dan upah di perkotaan yang cenderung lebih tinggi dibanding perdesaan, mendorong individu untuk mencari kerja ke perkotaan, sehingga lebih banyak orang yang bersaing untuk mendapatkan pekerjaan (BaahBoateng, 2015) di Ghana tahun 2008 dan 2013.

4. Jenis kelamin

Laki-laki memiliki probabilitas menjadi pengangguran lebih kecil dibanding perempuan (Baah-Boateng, 2015; Ahmad \& Azim, 2010) di Ghana tahun 2008, 2013 dan di Pakistan tahun 2006-2007.

5. Status kawin

Individu yang berstatus kawin memiliki probabilitas lebih kecil menjadi pengangguran dibanding yang berstatus belum kawin (Baah-Boateng, 2015; Ahmad \& Azim, 2010) di Ghana tahun 2008, 2013 dan di Pakistan tahun 2006-2007.

6. Status sebagai kepala rumah tangga (KRT) Individu yang berstatus KRT memiliki kecenderungan bekerja lebih tinggi dibanding yang bukan KRT. Rasa tanggungjawab untuk membiayai keluarga, mendorong individu untuk bekerja (Ahmad \& Azim, 2010) di Pakistan tahun 2006-2007.

7. Upah minimum

Kenaikan upah minimum memiliki pengaruh yang kecil pada peningkatan pengangguran pekerja muda. Hal ini dapat disebabkan bahwa masih banyak perusahaan 
yang belum menerapkan kebijakan upah minimum (Bhorat et al., 2016; Belchamber, 2004) di Afrika Selatan tahun 2000-2007.

\section{METODE}

Data yang digunakan dalam penelitian ini adalah data cross section antara dua titik waktu yaitu Agustus 2019 dan Agustus 2020. Sumber data berasal dari Survei Angkatan Kerja Nasional (Sakernas). Unit analisisnya yaitu individu yang lulus dalam setahun terkahir dengan umur 15-32 tahun dari tingkat pendidikan minimal SMP dan bekerja atau menganggur (fresh graduate). Sedangkan fresh graduate bekerja dibatasi untuk yang berpengalaman kerja $\leq 12$ bulan.

Metode yang digunakan dalam penelitian ini :

1. Analisis Deskriptif untuk menggambarkan hubungan antara masing-masing variabel independent terhadap status bekerja fresh graduate dengan menggunakan tabulasi silang.

2. Analisis Inferensia, dengan regresi logistik biner untuk model 1 dan regresi logit multilevel dengan menambahkan variabel makro yaitu Upah Minimum Provinsi (UMP) sebagai variabel kontrol untuk model 2.

a. Model regresi logistik (Nachrowi, 2002)

$$
\begin{gathered}
P_{i}=P\left(Y_{i}=1 \mid X_{i}\right) \\
P_{i}=\frac{e^{z}}{1+e^{z}} \\
\frac{P_{i}}{1-P_{i}}=e^{z} \\
\text { Model Logit }: L_{i}=\ln \left(\frac{P_{i}}{1-P_{i}}\right)=z= \\
\beta_{0}+\beta_{1} X_{1}+\beta_{2} X_{2}+\cdots+\beta_{i} X_{i}+\mu_{i}
\end{gathered}
$$

Setelah koefisien hasil regresi logistik diperoleh, kemudian dilakukan uji simultan dan uji parsial untuk memeriksa signifikansi.

- Uji Simultan : Uji signifikansi model secara keseluruhan

$\mathrm{H}_{\mathrm{o}}: \beta_{1}=\beta_{2}=\ldots=\beta_{\mathrm{p}}=0$
$\mathrm{H}_{1}$ : Minimal ada satu $\beta_{\mathrm{j}} \neq 0$

Statistik Uji menggunakan uji $\mathrm{G}$ (likelihood ratio test)

$$
G=-2 \ln \left(\frac{\text { Likelihood }_{A}}{\text { Likelihood }_{B}}\right)
$$

Likelihood $_{A}$ : Model yang hanya terdiri dari konstanta

Likelihood $_{B}$ : Model yang terdiri dari semua variabel yang akan diolah

Statistik uji G mengikuti sebaran chi square dengan derajat bebas $\mathrm{p}$ (jumlah variabel independent dalam model)

Tolak Ho bila $G>X_{\alpha, p}^{2}$ dimana $\alpha$ : tingkat signifikansi, maka model signifikan pada tingkat signifikansi $\alpha$

- Uji Wald: Uji signifikansi masingmasing koefisien

Ho : $\beta_{\mathrm{j}}=0, \mathrm{j}=0,1, \ldots . \mathrm{p}$

$\mathrm{H}_{1}: \beta_{\mathrm{j}} \neq 0$, variabel independent berpengaruh terhadap variabel dependent

Statistik uji yang digunakan adalah $W=\left[\frac{\widehat{\beta}_{j}}{\operatorname{se}\left(\widehat{\beta}_{j}\right)}\right]^{2}$

Ho ditolak bila $W>X_{\alpha, 1}^{2}$ maka $\beta_{\mathrm{j}}$ signifikan pada taraf signifikansi $\alpha$.

b. Model Regresi Logit Multilevel

Regresi logit multilevel (Aliyudin, 2017) dilakukan saat variabel independent berstruktur hierarki, terdapat perbedaan level yaitu level individu (level 1) dan level provinsi (level 2) yang diregress bersamaan. Pada regresi multilevel dilakukan estimasi pada komponen varian yang menunjukan random effect variabel pada level 2 terhadap level 1. Interpretasi hasil sama seperti regresi logistik biasa.

Berikut dijabarkan variabel-variabel yang akan diolah dan dianalisis: 
Tabel 1. Definisi Operasional Variabel

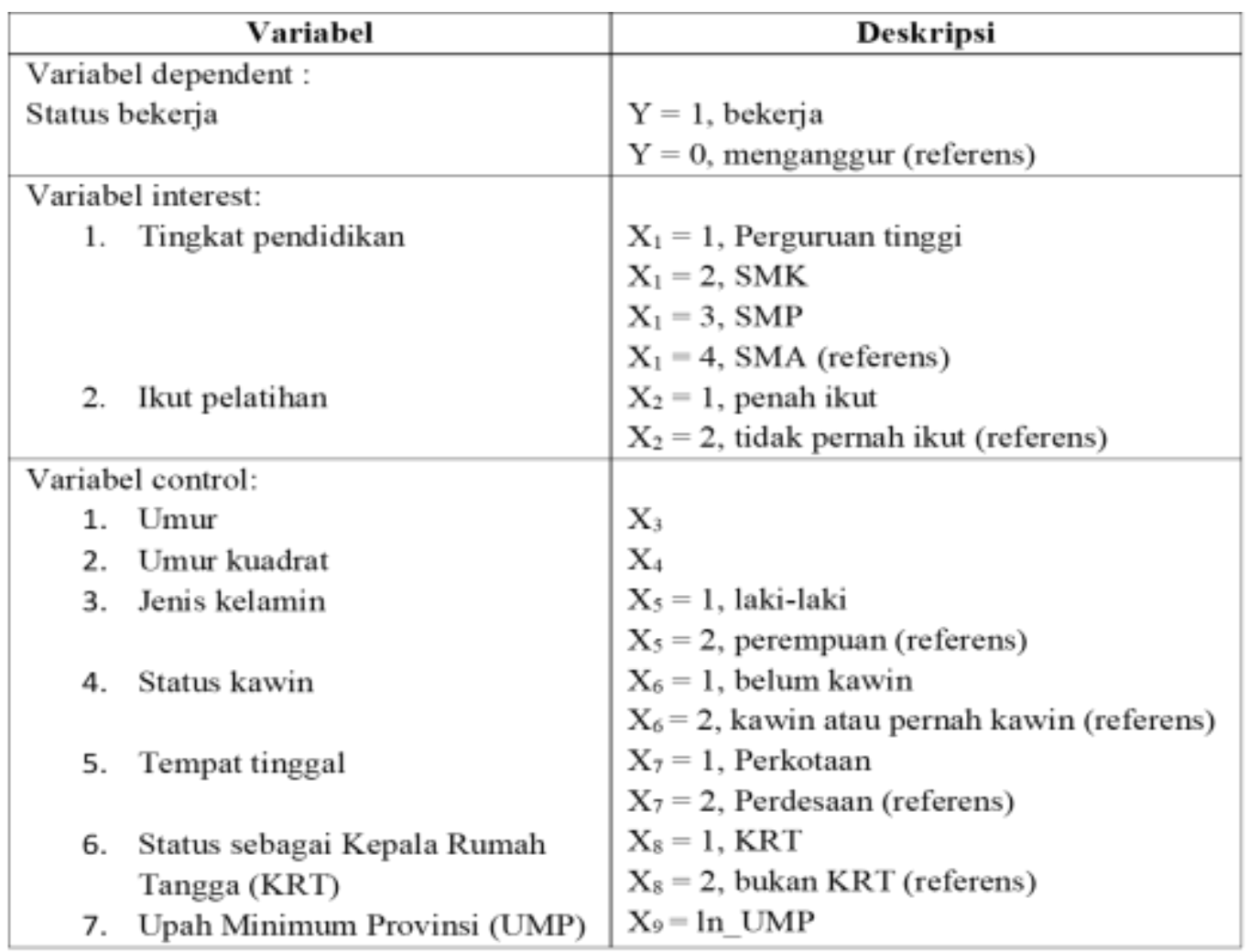

\section{HASIL DAN PEMBAHASAN}

1. Analisis Deskriptif

Dengan menggunakan individual weighted, sehingga sampel dapat mewakili populasi dan dapat diperbandingkan antara tahun 2019 dan 2020. Pada tahun 2020, jumlah fresh graduate meningkat $11,58 \%$ dibanding tahun 2019, dari 5.605.706 menjadi 6.254.677 pada tahun 2020 .

Tabel 2. Jumlah dan Persentase Fresh Graduate Tahun 2019 dan 2020

\begin{tabular}{|c|c|c|c|c|}
\hline & \multicolumn{2}{|c|}{2019} & \multicolumn{2}{|c|}{2020} \\
\hline & $\begin{array}{l}\text { Jumlah } \\
(\mathbf{N})\end{array}$ & $\begin{array}{l}\text { Persentase } \\
\quad(\%)\end{array}$ & $\begin{array}{c}\text { Jumlah } \\
(\mathbf{N})\end{array}$ & $\begin{array}{l}\text { Persentase } \\
\quad(\%)\end{array}$ \\
\hline (1) & (2) & (3) & (4) & (5) \\
\hline Fresh graduate & 5.605 .706 & 100.00 & 6.254 .677 & 100.00 \\
\hline $\begin{array}{l}\text { Fresh graduate Bukan Angkatan } \\
\text { kerja }\end{array}$ & 3.190 .160 & 56.91 & 3.784 .584 & 60.51 \\
\hline Fresh graduate Angkatan kerja & 2.415 .546 & 43.09 & 2.470 .093 & 39.49 \\
\hline a. Bekerja & 1.323 .603 & 54.80 & 1.293 .775 & 52.38 \\
\hline b. Menganggur & 1.091 .943 & 45.20 & 1.176 .318 & 47.62 \\
\hline
\end{tabular}

Pada tahun 2020, persentase fresh graduate yang termasuk angkatan kerja lebih rendah dibanding tahun 2019. Persentase yang bekerja juga lebih rendah, sedangkan persentase yang menganggur lebih tinggi $2.42 \%$ poin dibanding tahun 2019.
Secara rata-rata, umur fresh graduate pada tahun 2019 dan 2020 adalah 20 tahun. Pada tahun 2020, persentase fresh graduate lulusan perguruan tinggi, SMA, dan SMK yang bekerja lebih rendah dibanding tahun 2019. Sedangkan lulusan SMP, persentase yang bekerja lebih 
tinggi 4.9\% poin dibanding tahun 2019 (Tabel 3). Dari sisi supply, individu lulusan SMP cenderung tidak memiliki pilihan pekerjaan dan bersedia bekerja dengan upah yang lebih rendah untuk memenuhi kebutuhan hidup. Dari sisi demand, pandemi covid 19 yang melanda menyebabkan banyak perusahaan mengalami penurunan permintaan output sehingga menimbulkan peningkatan pengangguran.
Pada tahun 2020, persentase fresh graduate pernah mengikuti pelatihan yang bekerja lebih rendah dibanding tahun 2019 (Tabel 3). Upah Minimum Provinsi tahun 2019 berkisar antara $1,570,922$ sampai 3,940,973 dan pada tahun 2020 berkisar antara $1,742,015$ sampai 4,67,349.

Tabel 3. Persentase Status Bekerja Fresh Graduate Menurut Variabel Independent Kategorik

\begin{tabular}{|c|c|c|c|c|c|c|}
\hline \multirow[t]{2}{*}{ Variabel } & \multicolumn{3}{|c|}{2019} & \multicolumn{3}{|c|}{2020} \\
\hline & $\begin{array}{c}\text { Menganggur } \\
(\%)\end{array}$ & $\begin{array}{c}\text { Bekerja } \\
(\%)\end{array}$ & $\begin{array}{c}\text { Total } \\
(\%)\end{array}$ & $\begin{array}{c}\text { Menganggur } \\
(\%)\end{array}$ & $\begin{array}{c}\text { Bekerja } \\
(\%)\end{array}$ & $\begin{array}{c}\text { Total } \\
(\%)\end{array}$ \\
\hline (1) & $(2)$ & (3) & (4) & (5) & (6) & $(7)$ \\
\hline \multicolumn{7}{|c|}{ Tingkat Pendidikan } \\
\hline Perguruan tinggi & 41.1 & 58.9 & 100 & 45.6 & 54.4 & 100 \\
\hline SMK & 50.1 & 49.9 & 100 & 51.9 & 48.1 & 100 \\
\hline SMP & 24.6 & 75.4 & 100 & 19.7 & 80.3 & 100 \\
\hline SMA (referens) & 46.1 & 53.9 & 100 & 50.0 & 50.0 & 100 \\
\hline Total & 45.2 & 54.8 & 100 & 47.6 & 52.4 & 100 \\
\hline \multicolumn{7}{|l|}{ Pelatihan } \\
\hline Pernah ikut & 41.3 & 58.7 & 100 & 46.4 & 53.6 & 100 \\
\hline Tidak pernah & 45.9 & 54.1 & 100 & 48.0 & 52.0 & 100 \\
\hline Total & 45.2 & 54.8 & 100 & 47.6 & 52.4 & 100 \\
\hline \multicolumn{7}{|l|}{ Jenis kelamin } \\
\hline Laki-laki & 47.1 & 52.9 & 100 & 48.2 & 51.8 & 100 \\
\hline Perempuan & 43.4 & 56.6 & 100 & 47.1 & 52.9 & 100 \\
\hline Total & 45.2 & 54.8 & 100 & 47.6 & 52.4 & 100 \\
\hline \multicolumn{7}{|l|}{ Tempat tinggal } \\
\hline Perkotaan & 45.7 & 54.3 & 100 & 50.8 & 49.2 & 100 \\
\hline Perdesaan & 44.2 & 55.8 & 100 & 42.2 & 57.8 & 100 \\
\hline Total & 45.2 & 54.8 & 100 & 47.6 & 52.4 & 100 \\
\hline \multicolumn{7}{|l|}{ Status kawin } \\
\hline Belum kawin & 45.7 & 54.3 & 100 & 48.1 & 51.9 & 100 \\
\hline Kawin/pernah & 29.5 & 70.5 & 100 & 29.3 & 70.7 & 100 \\
\hline Total & 45.2 & 54.8 & 100 & 47.6 & 52.4 & 100 \\
\hline \multicolumn{7}{|l|}{ Status KRT } \\
\hline KRT & 26.3 & 73.7 & 100 & 36.0 & 64.0 & 100 \\
\hline Bukan KRT & 45.7 & 54.3 & 100 & 47.8 & 52.2 & 100 \\
\hline Total & 45.2 & 54.8 & 100 & 47.6 & 52.4 & 100 \\
\hline
\end{tabular}

2. Analisis Inferensia

Analisis inferensia menggunakan dua model yaitu model 1 menggunakan regresi logistik biner, tanpa menambahkan variabel UMP dan model 2 menggunakan regresi logit multilevel, dengan menambahkan variabel UMP sebagai variabel kontrol.

Setelah dikontrol oleh variabel lain, lulusan perguruan tinggi memiliki kecenderungan bekerja lebih rendah dibanding lulusan SMA. Pada model 1 dan model 2 tahun 2019, kecenderungan fresh graduate untuk bekerja dibandingkan menganggur pada lulusan perguruan tinggi, masing-masing sebesar 0.751 kali dan 0.730 kali dibanding lulusan SMA, sedangkan pada tahun 2020 kecenderungannya untuk bekerja sedikit lebih tinggi dibanding tahun 2019 yaitu 0.832 kali untuk model 1 dan 0.781 kali untuk model 2 dibanding lulusan SMA (tabel 4). Hasil studi Willis Towes Watson dalam (Kementerian Ketenagakerjaan, 2020) mengungkapkan bahwa delapan dari sepuluh 
perusahaan di Indonesia kesulitan mendapatkan lulusan yang sesuai dengan kualifikasi dan siap pakai. Dalam World Education News Review tahun 2019 dalam (Kementerian Ketenagakerjaan, 2020), disebutkan bahwa kurikulum pendidikan belum sesuai dengan kebutuhan pasar tenaga kerja dengan kemajuan teknologi yang semakin pesat. Senada dengan studi sebelumnya, dalam penelitian (Handayani, 2015) menyebutkan bahwa merebaknya perguruan tinggi baru menyebabkan jumlah lulusan perguruan tinggi bertambah tetapi tidak diikuti dengan kualitas pendidikan yang sesuai dengan kebutuhan skill di pasar kerja.

Tabel 4. Hasil Regresi Logistik dan Multilevel Pengaruh Education Terhadap Kecenderung Bekerja Pada Fresh Graduate

\begin{tabular}{|c|c|c|c|c|c|c|c|c|}
\hline & \multicolumn{4}{|c|}{2019} & \multicolumn{4}{|c|}{2020} \\
\hline & \multicolumn{2}{|c|}{ Model 1} & \multicolumn{2}{|c|}{ Model 2} & \multicolumn{2}{|c|}{ Model 1} & \multicolumn{2}{|c|}{ Model 2} \\
\hline & $\boldsymbol{\beta}$ & $\begin{array}{l}\text { Odd } \\
\text { rasio }\end{array}$ & $\boldsymbol{\beta}$ & $\begin{array}{l}\text { Odd } \\
\text { rasio }\end{array}$ & $\boldsymbol{\beta}$ & $\begin{array}{l}\text { Odd } \\
\text { rasio }\end{array}$ & $\beta$ & $\begin{array}{l}\text { Odd } \\
\text { rasio }\end{array}$ \\
\hline (1) & (2) & (3) & (4) & (5) & (6) & (7) & (8) & (9) \\
\hline \multicolumn{9}{|c|}{ Variabel interest : } \\
\hline PT & $-0.286^{*}$ & 0.751 & $-0.315^{*}$ & 0.730 & $-0.184^{*}$ & 0.832 & $-0.247^{*}$ & 0.781 \\
\hline SMK & $-0.136^{*}$ & 0.873 & $-0.126^{*}$ & 0.882 & $-0.050^{*}$ & 0.951 & $0.014 *$ & 1.014 \\
\hline SMP & $1.302^{*}$ & 3.678 & $1.314^{*}$ & 3.721 & $1.660^{*}$ & 5.260 & $1.731^{*}$ & 5.648 \\
\hline Ikut pelatihan & $0.136^{*}$ & 1.146 & $0.076^{*}$ & 1.079 & $0.095^{*}$ & 1.100 & $0.101 *$ & 1.107 \\
\hline $\begin{array}{l}\text { Variabel kontr } \\
\text { Umur }\end{array}$ & $0.257 *$ & 1.293 & $0.191 *$ & 1.210 & $0.208^{*}$ & 1.231 & $0.242 *$ & 1.274 \\
\hline Umur kuadrat & $-0.004 *$ & 0.996 & $-0.003^{*}$ & 0.997 & $-0.003^{*}$ & 0.997 & $-0.004 *$ & 0.996 \\
\hline Laki-laki & $-0.154 *$ & 0.857 & $-0.157^{*}$ & 0.854 & $-0.082 *$ & 0.921 & $-0.120 *$ & 0.887 \\
\hline Belum kawin & $-0.485^{*}$ & 0.616 & $-0.453^{*}$ & 0.636 & $-0.660 *$ & 0.517 & $-0.629 *$ & 0.533 \\
\hline Perkotaan & $-0.052 *$ & 0.950 & $0.019 *$ & 1.019 & $-0.302 *$ & 0.739 & $-0.114 *$ & 0.892 \\
\hline Status KRT & $0.788^{*}$ & 2.198 & $0.700 *$ & 2.013 & $0.467 *$ & 1.595 & $0.427 *$ & 1.533 \\
\hline $\ln \_$UMP & & & $-1.525^{*}$ & 0.218 & & & -0.432 & 0.649 \\
\hline
\end{tabular}

Ket : Referens (SMA, tidak pernah ikut pelatihan, perempuan, kawin/pernah kawin, perdesaan,)

*) signifikan pada $\alpha=0.01$

Pada tahun 2019, jumlah lulusan perguruan tinggi swasta sebanyak 997.116 orang, sedangkan perguruan tinggi negeri hanya setengahnya yaitu 524.718 orang. Jumlah perguruan tinggi swasta sebanyak 3.129, sedangkan perguruan tinggi negeri hanya 122 . Terdapat $48 \%$ perguruan tinggi belum terakreditasi, sedangkan yang terakreditasi A hanya sebanyak $2 \%$, terakreditasi B sebanyak $18 \%$, dan terakreditasi C sebanyak $32 \%$ (Kemenristekdikti, 2019). Hal ini harus menjadi perhatian pemerintah dalam meningkatkan kualitas perguruan tinggi agar lulusan yang dihasilkan berkualitas dan berdaya sain.

Walaupun kecenderungan lulusan perguruan tinggi dan SMK untuk bekerja dibanding lulusan SMA lebih rendah, namun nilainya menunjukan sedikit peningkatan pada tahun 2020 dibanding tahun 2019. Hal ini sesuai dengan penelitian (Song \& Riddell, 2011) bahwa tingkat pendidikan meningkatkan kemampuan dalam menghadapi kondisi ekonomi. Pada tahun 2020, terdapat sektor usaha yang tumbuh dengan angka pertumbuhan sampai 2 digit yaitu informasi dan komunikasi sebesar 10,58\% dan jasa kesehatan sebesar $11,6 \%$. Hal ini membuka peluang lulusan pada jurusan yang berkaitan dengan sektor tersebut untuk bekerja. Pada jenjang perguruan tinggi, sekitar lebih dari $70 \%$ lulusan kesehatan dan teknologi informasi bekerja, begitu juga dengan lulusan SMK pada jurusan tersebut (Sakernas 2020, diolah). 


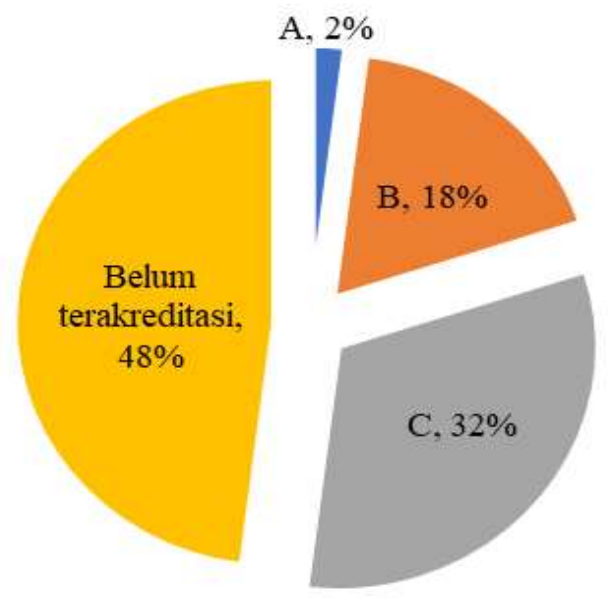

Sumber: Kementerian Riset, Teknologi, Pendidikan Tinggi

Gambar 3. Akreditasi Perguruan Tinggi Tahun 2019 (\%)

Berkebalikan dengan lulusan perguruan tinggi, lulusan SMP memiliki kecenderungan fresh graduate untuk bekerja sebesar 3.678 kali pada tahun 2019 dan meningkat signifikan menjadi 5.260 kali pada tahun 2020 dibanding dengan lulusan SMA (model 1). Pada model 2, kecenderungan lulusan SMP untuk bekerja dibanding dengan lulusan SMA pada tahun 2020 juga lebih tinggi dibanding tahun 2019, yaitu sebesar 3.721 kali pada tahun 2019 dan 5.648 kali pada tahun 2020 .

Fresh graduate yang pernah ikut pelatihan memiliki kecenderungan lebih besar untuk bekerja dibanding yang tidak pernah ikut pelatihan. Pada model 1 tahun 2020, fresh graduate yang pernah ikut pelatihan memiliki kecenderungan bekerja lebih rendah dibanding tahun 2019, sedangkan pada model 2 kecenderungannya menunjukan nilai yang lebih tinggi.

Kecenderungan bekerja menurut umur, memiliki pola $U$ terbalik, dimana peningkatan umur meningkatkan kecenderungan bekerja, namun pada titik umur tertentu kecenderungan bekerja semakin menurun. Pada tahun 2019 dan 2020, fresh graduate perempuan memiliki kecenderungan bekerja lebih tinggi dibanding laki-laki. Kecenderungan fresh graduate berstatus belum kawin dan berstatus bukan Kepala Rumah Tangga (bukan KRT) untuk bekerja lebih rendah dibanding yang bersatus kawin atau pernah kawin dan KRT. Pada fresh graduate baik yang belum kawin, atau yang bukan KRT cenderung belum ada tanggungan, sehingga dapat lebih memilih pekerjaan yang sesuai. Pada model 2 tahun 2019, kecenderungan fresh graduate yang bekerja di perkotaan lebih tinggi dibanding di perdesaan, sedangkan pada model 1 tahun 2019 dan 2020 serta model 2 tahun 2020, fresh gradute yang tinggal di perkotaan memiliki kecenderungan untuk bekerja lebih rendah dibanding di perdesaan dan kecenderungannya semakin rendah pada tahun 2020 dibanding 2019. Pandemi covid 19 yang membuat sektor ekonomi terpukul, semakin menambah saingan untuk mendapatkan pekerjaan. Sektor pertanian merupakan sektor yang justru mengalami pertumbuhan pada masa pandemi, turut memengaruhi status bekerja fresh graduate yang tinggal di perdesaan. Pada tahun 2019, UMP signifikan memengaruhi kecenderungan fresh graduate bekerja. Kenaikan 1\% UMP akan menurunkan kecenderungan fresh graduate untuk bekerja sebesar 0.218 kali. Kenaikan UMP akan meningkatkan cost yang harus dikeluarkan perusahaan, sehingga untuk memaksimumkan keuntungannya, perusahaan mempekerjakan pekerja lebih sedikit. Namun pada tahun 2020, UMP tidak signifikan memengaruhi kecenderungan bekerja, karena keadaan ekonomi yang mengalami resesi lebih memengaruhi kecenderungan bekerja.

\section{KESIMPULAN DAN SARAN}

Pada tahun 2019 dan 2020, persentase fresh graduate yang memasuki pasar kerja lebih 
sedikit dibanding yang tidak memasuki pasar kerja. Namun persentasenya lebih rendah di tahun 2020. Persentase fresh graduate yang menganggur mengalami peningkatan $2.42 \%$ poin dari tahun 2019.

Setelah dikontrol oleh variabel lain, tingkat pendidikan berhubungan signifikan dengan kecenderungan fresh graduate bekerja. Namun, lulusan perguruan tinggi memiliki kecenderungan bekerja lebih rendah dibanding lulusan SMA. Lulusan SMP memiliki kecenderungan bekerja lebih tinggi dibanding lulusan SMA. Lulusan perguruan tinggi yang semakin banyak tidak selalu sesuai dengan skill yang dibutuhkan di pasar kerja. Selama pandemi covid 19 (tahun 2020), kecenderungan fresh graduate lulusan perguruan tinggi untuk bekerja sedikit lebih tinggi dibanding sebelum covid 19 (tahun 2019). Sedangkan fresh graduate yang pernah mengikuti pelatihan berhubungan positif dan signifikan terhadap kecenderungan bekerja baik pada tahun 2019 maupun tahun 2020. Dengan kecenderungan yang juga sedikit lebih tinggi pada tahun 2020 dibanding tahun 2019. Diperlukan peningkatan kualitas perguruan tinggi dengan memberikan mata kuliah yang relate diaplikasikan di dunia kerja, mendatangkan praktisi-praktisi di dunia kerja yang expert di bidangnya, dan mendorong akreditasi universitas.

Pada tahun 2019, kenaikan UMP menurunkan kecenderungan fresh graduate bekerja, namun pada tahun 2020, UMP tidak berpengaruh pada kesenderungan tersebut. Hal ini dapat dikarenakan karena kondisi ekonomi yang sedang mengalami kontraksi pertumbuhan sebesar $-2.07 \%$. Kenaikan UMP harus ditentukan secara wajar sehingga tidak memberatkan pelaku usaha, yang pada akhirnya mengurangi tenaga kerja yang dihire.

\section{DAFTAR PUSTAKA}

Ahmad, R., \& Azim, P. (2010). Youth Population and the Labour Market of Pakistan: a Micro Level Study. Pakistan Economic and Social Review, 48(2), 183-208.

Aliyudin, F. (2017). PERSALINAN WANITA USIA SUBUR DI INDONESIA
MENGGUNAKAN DATA SDKI 2012 ( APLIKASI ANALISIS REGRESI LOGISTIK BINER MULTILEVEL ). 2012, 33-46.

Baah-Boateng, W. (2015). Unemployment in Ghana: a cross sectional analysis from demand and supply perspectives. African Journal of Economic and Management Studies, 6(4), 402-415. https://doi.org/10.1108/AJEMS-11-20140089

Becker, G. S. (1962). Investment in Humancapital: A Theoretical Analysis. The Journal of Political Economy, 70(5), 9-49.

Belchamber, G. (2004). Minimum wages and youth employment. In Labour education. No. 136 (Vol. 09707).

Bhorat, H., Cassim, A., Kanbur, R., Stanwix, B., \& Yua, D. (2016). Minimum wages and youth: The case of South Africa. Journal of African Economies, 25(June 2019), i61i102. https://doi.org/10.1093/jae/ejv029

Borjas, G. J. (2014). Labor Economics (Seventh Ed). Mc Graw Hill Education.

BPS. (2020). Keadaan Ketenagakerjaan Indonesia Agustus 2020. In Badan Pusat Statistik: Vol. No.86/11/T (Issue 91). https://www.bps.go.id/publication/

eurostat. (2021). Employment rates of recent graduates.

https://ec.europa.eu/eurostat/statisticsexplained/index.php?title=Employment_ra tes_of_recent_graduates\#Employment_rate s_of_recent_graduates

Handayani, T. (2015). Relevansi Lulusan Perguruan Tinggi Di Indonesia Dengan Kebutuhan Tenaga Kerja Di Era Global. Jurnal Kependudukan Indonesia, 10(1), 53. https://doi.org/10.14203/jki.v10i1.57

Hooley, T. (2020). Covid-19: Global impacts on graduate recruitment (Issue July).

Kemenristekdikti. (2019). Statistik Pendidikan Tinggi (Higher Education Statistics) 2019. In Pusdatin Kemenristekdikti. http://www.mohe.gov.my/web_statistik/

Kementerian Ketenagakerjaan. (2020). Analisis Dampak Pandemi Covid-19 Terhadap Perluasan Kesempatan Kesempatan Kerja 
dan Implikasinya.

Mankiw, N. G. (2020). Principles of Economics Ninth Edition. Lean Assembly; Cengage. https://doi.org/10.4324/9781482293722intr

Nachrowi, D. N. U. (2002). Penggunaan Teknik Ekonometrika (Edisi 1).

Song, X., \& Riddell, W. C. (2011). The Impact of Education on Unemployment Incidence and Re-employment Success: Evidence from the U.S. Labour Market. Labour Economics, 18(47), 453-463.

Wikipedia.

(2021).

Pemuda. https://en.wikipedia.org/wiki/Youth Wittekind, A., Raeder, S., \& Grote, G. (2010). A longitudinal study of determinants of perceived employability. Journal of Organizational Behavior, 31(4), 566-586. https://doi.org/10.1002/job.646 